\title{
Local Concerns: Suicide and Jury Behavior in Medieval England
}

Sara M. Butler*

Loyola University New Orleans

\begin{abstract}
When confronted with cases of self-killing, medieval jurors had to contend with a vast array of often conflicting concerns, from religious and folkloric condemnations of the act of suicide, to fears for the welfare of the family of the dead, and to coping with royal confiscations of a felon's goods. All of these factors had a profound impact on the verdicts put forward by members of the jury during the various stages of the legal process. While these elements form the base of jury verdicts relating to self-killings, it must nevertheless be acknowledged that medieval juries did not respond uniformly to cases of suicide. Rather, jurors at various stages of the process differed widely in their familiarity with the dead and this familiarity had an impact on their judgments. Members of the coroners' inquest juries were often neighbors of the dead, and thus their verdicts reflected a more local resolution to the death of a community member than the verdicts of presentment or trial juries.
\end{abstract}

The role of the jury in the English criminal legal process has, of late, become a focal point for understanding medieval English law in practice. Increasingly, historians have come to realize that juries played a central role as guardians of communal values, often imposing a sense of justice on the courts that conflicted fundamentally with the theory of the law. From incomparably high acquittal rates to the widespread use of legal fictions, medieval juries developed ways of operating within the constraints of a harsh and ostensibly rigid legal system, seemingly without compromising their own complex code of communal beliefs. ${ }^{1}$ For example, where the law drew no distinction between homicide and what we today would describe as manslaughter, jurors did, and seem to have been perfectly willing to fabricate evidence to acquit or pardon those who killed in "hot blood." This process of jury nullification is particularly interesting when isolated to instances of suicide, known as felo[nia] de se. Contrasting conceptions of justice between local communities and the crown came to a head in cases of suicide. Where the king was fundamentally interested in profits, the jury had a much broader array of concerns from economics to religion to popular fears of ghosts. This essay seeks to provide an overview of the question of jury behavior in late medieval England, by looking at the treatment of suicides by inquest, 
presentment, and trial juries from the thirteenth to the early sixteenth centuries. Building on a survey of recent literature on suicide and on the jury, I will use some of the findings of my own research to show what the records can tell us about jury behavior.

\section{Attitudes towards Suicide}

More than most other crimes, suicide elicited conflicting responses from the crown and jurors were assigned to pass judgment on it. On the one hand, the king and his officials saw suicide as an opportunity to profit. Since the mid-thirteenth century, English kings had claimed the right to confiscate the lands and chattels of self-killers for the period of a year and a day, as if it were any other felony. The only exemptions were cases where jurors found the defendant to be non compos mentis (not of sound mind), thus incapable of being held responsible for his or her crimes. While the notion of the state profiting from justice may be uncongenial to modern thinking, medieval kings understood the law to be a valuable source of income, which they exploited in a variety of creative ways during times of war or financial need. ${ }^{3}$ When presented with a case of suicide, then, the primary concerns of the crown were not only to uphold justice and keep the peace, but also to ensure the seizure of forfeited assets and limit the control of local officials who might impede the swelling of the royal treasure through graft or local sympathies.

English juries, on the other hand, had a much more diverse range of concerns to address, and were often required to negotiate carefully between royal and local sentiments. While jurors most likely feared retribution for evading the law, their judgments must have been tempered by genuine concern for a suicide's family as they faced the prospect of destitution. Thus, the jurors who issued a declaration of suicide coped with a double burden: guilt for impoverishing the family and concern for the community to whom that family would become a burden.

Forfeiture by the crown was but one factor in a jury's decision. Suicide in the medieval period was interpreted in light of Christian perceptions, for not only was suicide considered to be a profoundly evil act contrary to God's intentions, but the medieval church also understood suicide as an act of despair, an unpardonable sin because it symbolized a rejection of Christ. ${ }^{4}$ This had further implications on the family of a suicide. A suicide was prohibited from having his or her name entered on the bederoll (a local parish's prayer list for souls of the departed), excluding their family from the cult of the dead by disallowing official intercession for the soul of the self-killer in Purgatory. This practice, which Eamon Duffy has described as an "obsession" among the late medieval English, effectively prevented family members from mourning properly for their lost kin, further complicating the situation. ${ }^{5}$ Perhaps even more pertinent, as Paul Binski writes, "[1]ate-medieval sermons still clung on to the idea that those not properly 
honoured in death or memory could be angry or even dangerous," hence families had much to fear if deprived of their rights to honor the dead. ${ }^{6}$

Burial practices associated with suicides across Europe would also suggest that folklore played an important role in forming perceptions of suicide. Although the Catholic Church refused burial in consecrated ground to perpetrators of suicide, it did not stipulate how a self-killer should be buried. Yet, across Europe, they were often interred in a barbaric, ritualistic fashion. For example, in thirteenth-century Lille, the body of a male suicide was dragged to the gallows then hanged, while a female suicide's body was burned. ${ }^{7}$ In the case of medieval England, the evidence is much less conclusive. Some historians and archaeologists have argued that barbaric rituals associated with the burial of suicides can be traced as far back as the Anglo-Saxon period, although clear proof exists only from the early sixteenth century. ${ }^{8}$ This evidence demonstrates that villagers buried the body of a suicide at a crossroads, with a wooden stake driven through the chest, pinning the body to the ground. ${ }^{9}$ The execution of the corpse, common to all these practices, had very practical aims. As a deterrent, it is hard to imagine a more powerful spectacle than such a brutal method of burial. More importantly, popular burial practices addressed legitimate fears of the supernatural as medieval men and women suffered from a very real terror of ghosts. Believing that those who died without a proper funeral and mourning rituals would come back to haunt the living, burials of this nature acted as a "rite of exorcism," at once expelling the spirit and assuaging popular fears of the dead. ${ }^{10}$ Most poignantly, however, the pageantry of interment acted as "a dreadful trial for the suicide's nearest kin, who were forced to watch a public spectacle that brought dishonor to the entire family group." 11

Given the indignity attached to a declaration of suicide for the family of the dead, it is not surprising that as early as 1970 historians accused both jurors and royal officials of rewriting contemporary events out of sympathy for the families, by judging intentional drowning as accidents, deliberate self-killings as the product of insanity, and simply concealing or failing to report suicides. ${ }^{12}$ What needs to be taken into consideration, however, is that jurors, even as representatives of the broader English community, were not uniform in their perceptions and priorities. Concerns about crown forfeiture, the damnation facing a suicide, the dishonor of a suicide's family and their exclusion from the cult of the dead, and the fear of ghosts that lay at the base of communal values regarding suicide, were certainly more pertinent to some jurors than to others.

The coroner's inquest lies at the heart of the issue. Alexander Murray has argued that, "coroners, being local, were likely to be biased towards the excusing of suicides." ${ }^{13} \mathrm{He}$ sees that manipulation of allegations of insanity were most likely to occur at the level of the inquest. In theory, a finding of non compos mentis would not only have permitted a self-killer burial in consecrated ground, but it would also have barred the king from claiming any rights to the self-killer's goods or property. When inquest jurors alleged 
insanity, then, they did so in order to "giv[e] a suicide the benefit of the doubt." Therefore, "in the handful of split decisions" where coroner's inquest and presentment juries return contrasting verdicts, Murray argues "it is more often than not the coroner who gives the milder one." ${ }^{14}$ Here, it is important to note that while both inquest and presentment jurors hailed from the community where the felony occurred, there was a marked difference in the composition of the juries. Originally inquest jurors were intended to represent the four neighboring townships, but often they were recruited from the immediate neighborhood in which the crime had taken place. ${ }^{15}$ Thus, it is likely the jurors were neighbors of, or at least acquainted with, the deceased. Presentment juries, however, were composed of "local notables," determined to "identify offenders considered to be beyond the control of local authorities." ${ }^{16}$ Such conflicting credentials surely influenced their judgments. Prevailing opinions concerning the place of the coroners' rolls in the study of medieval England emphasize the local bias of their judgments. Carrie Smith notes that "much of their value [lies] in what they tell us about community solidarity and the astuteness of community responses to royal officials." ${ }^{17}$ Just how far coroners' juries were willing to manipulate the narrative of events to exculpate a suicide is still at question. Roger Groot, for example, has gone so far as to argue that some inquest juries may have preferred not to acknowledge suicide as a felony at all. ${ }^{18}$ Gwen and Alice Seabourne represent the other side of the debate: they argue that historians' perceptions of leniency are influenced by modern attitudes toward suicide. Because "suicide is not now generally regarded as a matter which should be the subject of punishment," we assume "community leniency in opposition to harsh royal law." ${ }^{19}$

I will investigate further these assumptions about local values and local concerns in jurors' judgments of suicide by examining 718 records of self-killing, paying close attention to procedural variations in the records. A number of key questions need to be addressed: Did familiarity with the dead dictate a jury's inclination toward positive or negative emotions? Where local compassion influenced a jury's judgments, who were the beneficiaries of judicial lenience? Did jurors express sympathy only for the families of the deceased, or the self-killer also? When juries offered up harsh verdicts, what seems to have been the motivation?

\section{The Records}

Records of suicides from medieval England survive in both eyre or assize rolls (JUST 1), and coroners' rolls (JUST 2). Each offers a unique perspective. The eyre or assize rolls, extant in sufficiently large numbers to discourage exhaustive examination, offer a somewhat detached and pithy account of cases of suicide. A typical entry in an eyre roll reads as follows: "Roger le Whyte of Whitehall freely drowned himself in the river Thames. The first finder died. No one is suspected. Judgment: felonia de se. 
His chattels: five pence, for which the vill of Tilsworth will answer." ${ }^{20}$ The coroners' rolls, on the other hand, commonly include much more elaborate narratives reflecting the more intimate knowledge of the witnesses. Because only a small proportion of coroners' rolls have survived from the Middle Ages, records of this length and detail are rare. Another major factor is the period for which the source materials survive: the eyre or assize rolls belong largely to the thirteenth century, the coroners' rolls to the fourteenth. Thus, a comparison of the two kinds of records provides the opportunity to see the development of communal values about suicide across a period of time.

For the purposes of this study, an investigation of the collection of coroners' rolls at The National Archives in Kew, Surrey and roughly two eyre or assize rolls from each county has been undertaken, in addition to printed eyres, assizes and coroners' rolls. For two counties, Yorkshire and Essex, all surviving eyre and assize rolls were examined. The period under examination here runs from the thirteenth to the very early sixteenth century. The result of this array of sources is a grouping of 718 cases of self-killing from across England, with a disproportionate number appearing in the northern circuit (most likely because of the closer investigation by this author of Yorkshire records which report 135 self-killings, or roughly 19 percent of the total number of cases).

\section{Familiarity and Compassion}

Of the 718 cases of self-killings, 192 are found in the coroners' rolls, 526 in the eyre or assize rolls. An analysis of this grouping reveals significant discrepancies in people's views about suicide. Coroners' inquest juries appear to have been substantially more likely to excuse or, at the very least, not to condemn the act of self-killing. This bias is conspicuous in the inquest juries' repeated failure to note felonious intent. Of the 192 cases of self-killing appearing in the coroners' rolls, jurors employed the terms felonice (feloniously) or felonia (felony) in the narrative in only 41 of 192 cases, or 21 percent of the time..$^{21}$ In contrast, narratives of suicide in eyre or assize rolls employ one or both of the terms in 466 of the 526 cases, representing roughly 89 percent of cases. We cannot dismiss or easily rationalize such a vast disparity between narratives. On the simplest level, the formulaic nature of the records may explain the difference. Because an indictment was intended to be a "rigorously formal document that met every exacting technicality of the law,"22 records of suicides in eyre or assize rolls usually, though not always, conform to a set format, typical in the case of Roger le Whyte mentioned above, in which a formal statement of the jury's contentions was obligatory. Coroners' rolls, also notoriously laconic and formulaic, nonetheless regularly provide a more detailed account, and in cases of self-killing lack the uniformity apparent in the rolls classified as JUST 1. A little diversity, however, did not bar many coroners' juries from recording evidence of criminal intent (a feature also present in most homicide 
cases in coroners' rolls), and thus cannot account entirely for this dissimilarity. Why did the majority of coroners' juries choose not to describe self-killings as felonies? Because suicide was sometimes attributed to madness - a state that would render the suicide non compos mentis and thus exempt from royal confiscation of goods and lands - eyre jurors recognized the importance of assessing the deceased's state of mind. This requirement may explain the reluctance of coroners' juries to indict suicides. Thomas Green has argued that jurors were inclined "to shape the facts in the most positive way for many favored defendants;" 23 in the case of a suicide, "the most positive way" may have been an account that was deliberately ambiguous. Out of compassion for the deceased or his/her family, or even simply out of ignorance of the suicide's state of mind, coroners' jurors may have preferred to leave a case open to interpretation, with the anticipation that in omitting any discussion of intent a trial jury might be less likely subsequently to return a verdict of suicide. Because coroners' juries were less constrained by the demands of an overly exacting legal system, they were capable of extending this small gesture of compassion, where juries of presentment were not.

Open-ended verdicts were not the only indication that coroners' jurors acted mercifully toward suicides out of familiarity or compassion. Michael MacDonald and Terrence Murphy have observed that medieval juries had a "habit of sparing their neighbours by returning lenient verdicts." ${ }^{4}$ Alexander Murray has referred to this behavior as "softening the verdict." 25 We can interpret this purported leniency in one of two ways. First, a jury might attempt to describe as an accident an act of self-killing that was clearly deliberate. For example, a 1242 eyre roll from County Durham notes two cases of male suicides who hanged themselves. Their actions were described as mishaps, yet hanging oneself "by accident" must surely have been a rare occurrence? ${ }^{26}$ An accidental drowning is credible; an accidental hanging seems to indicate prevarication. Both coroners' and presentment jurors were somewhat prone to colorful accounts like this, but neither showed a proclivity for excusing self-killings as deaths by misadventure. ${ }^{27}$

Lenient verdicts came into play with traditional associations of self-killing with insanity. When they sought to absolve a suicide of guilt, jurors sometimes proffered evidence to show that the deceased had been incapable of understanding the consequences of his or her actions, owing either to a form of madness or to an illness or fever that produced a state of temporary insanity. Their deaths, these entries imply, were not felonious, but the consequences of misadventure. Both coroners' and presentment jurors sometimes put forward judgments of non compos mentis, although not to the extent claimed by MacDonald and Murphy. ${ }^{28}$ Although both kinds of juries made use of this explanation, coroners' juries resorted more frequently to allegations of insanity. Of the 192 cases of self-killing identified in the coroners' rolls, no fewer than 45 (or 23 percent) were described as being the product of mental deficiency; 53 of the 526 cases (or roughly 10 percent) 
of self-killings in the eyre or assize rolls received similar treatment. It is important to note, however, that in both kinds of evidence, jurors might also describe victims of insanity as felons. ${ }^{29}$ Coroners' jurors described three of the 45 madmen as felons (7 percent); in eyre or assize rolls, jurors described 28 of the 53 as such (53 percent). In the matter of insanity, then, there appears to have been a very real difference in the approach adopted by each kind of jury.

Local bias would seem also to be a logical explanation for some differences. Because most inquest jurors had a more intimate knowledge of the suicide (and his/her family), they may have been more apt to empathize with the family's plight. A judgment of misadventure would not only safeguard the suicide and his/her family's reputation, it would also prevent the family from becoming a strain on the financial resources of the community, an important concern for fellow villagers who were expected to extend a helping hand. An important qualitative difference in narratives of insanity reinforces the notion of compassion arising out of familiarity. While a wide variety of terms were applied to indicate mental instability (fury, frenzy, dementia, lunacy, madness), diabolical incitement - a very familiar literary theme from the period ${ }^{30}$ and one which MacDonald and Murphy contend was a frequent explanation for suicide by medieval jurors ${ }^{31}$ - was also employed in different ways in the two venues. In my findings, jurors of presentment attempt to rationalize a suicide's actions by blaming the devil only once, ${ }^{32}$ coroners' jurors, on the other hand, relied on this explanation a total of 13 times (out of 45 allegations of insanity appearing in the coroners' rolls, or roughly 29 percent).

How do we explain the frequency of these allegations in coroners' rolls? Fears of diabolical incitement may well have stemmed from genuine confusion and trauma over the loss of a neighbor or friend. Even today, friends and families of suicides often respond to the news with bafflement and incomprehension. In a notorious case of suicide that occurred in August 2000, Dr. Suzanne Killinger-Johnson, a well-known psychotherapist living in Toronto, leapt in front of a subway train with her infant son in her arms. The impact of the oncoming train instantly killed her baby; Killinger-Johnson lingered on life support for 10 days before she died. Those who knew her described her as "one of the most unlikely people to jump in front of a train," 33 and as having lived a "picture-perfect" 34 or "charmed" 35 life. Today, we often ascribe such unfathomable acts to depression induced by chemical imbalances in the brain (in Killinger-Johnson's case, to a rather prolonged postpartum depression). Medieval jurors, however, were incapable of enlisting the services of a scientific profession to explain the inexplicable, so how could an inquest jury, often composed of fellow villagers, have rationalized similar cases? Diabolical incitement, a form of insanity that required no history of madness, may have filled that void.

As a whole, the evidence indicates that the more intimate the juror, the more compassionate his judgment. Michael MacDonald and Terence Murphy 
attribute juridical lenience to consideration for the surviving family. Given that in 96 of the 526 cases of self-killing (or 18 percent) appearing before presentment jurors, the indictments cite charges laid against the locality for falsely appraising the chattels of the suicide (undervaluing them in an effort to spare the families), there is good reason to believe that this opinion is well founded. The records themselves, however, imply that the plights of the self-killers might sometimes have been sufficient motivation to exculpate a suicide. For example, a Cambridgeshire jury describes how Elena, wife of Thomas the Clerk of Barnwell, drowned herself because of the great sadness she had for her son. ${ }^{36}$ The death of Emma, daughter of William del Chyrche of Dent, falls into this category. A coroner's inquest jury probably realized that according to the law, Emma was responsible for any action taken to end her own life at the age of 14 . However, a more gentle and considerate judgment for the child's grieving father described her as having lost her mind, furious when she left his home, and was found dead soon after. $^{37}$

Given that local compassion encouraged judicial lenience on numerous occasions, it must be asked why jurors did not transform a larger number of suicides into deaths by misadventure. Certainly,Thomas Green has argued that juries were well accustomed to "the process of fact alteration," not just in cases of suicide, but in all kinds of felonies. ${ }^{38}$ Thus, instead of noting that Agnes de Assewell of Lincolnshire had been furious when she arose from her bed at dawn one morning and drowned herself in a well, why not say that she slipped on a rock while bathing and drowned - a common occurrence in the coroners' rolls? ${ }^{39}$ Or, when Thomas Fourlot, on a Sunday in September 1405, slew himself with an axe, why claim that he was mad? ${ }^{40}$ Why not describe the incident as a mishap brought about by negligence while chopping wood - again, apparently a widespread form of death by misadventure? In some cases, invention of this nature was simply not credible, and hanging surely falls into this category. Yet, jurors might have convincingly reinterpreted at least 67 drownings $^{41}$ and 36 stabbings found in the coroners' rolls into deaths by misadventure. The obvious reluctance of jurors to return manifestly creative verdicts shows that outright prevarication was not always possible or acceptable. Certainly, jurors must often have been concerned simply with telling the truth. But why did some inquest or presentment jurors feel inclined to report self-killings if they did not believe them to be felonious? B. W. McLane has asked a similar question about cases of homicide in which trial juries recast some deaths into scenarios of self-defense. He contends that jurors preferred to resort to a "hackneyed verdict" of self-defense because the circumstances "rendered outright acquittal inappropriate." ${ }^{42} \mathrm{~A}$ similarly strong sense of appropriate punishment may also explain accidental self-killings. While many jurors empathized with the families of suicides, and even some suicides themselves, suicide itself was a crime and a sin of a particularly scandalous nature, about which medieval Englishmen and women felt strongly. To conceal a suicide as an accident, 
some might say, would be to condone it; to present a self-killing, and then excuse it however balanced the equally rigorous demands of a social conscience torn between censure of the act and sympathy for the family and its loss.

Inquest and presentment juries, however, represented only the initial stages of the legal process; their judgments were not the last word on a matter. Trial juries composed of "twelve good men and true," who may or may not have known anything about the case and who probably did not hail from the same community as the cases upon which they were asked to sit in judgment, ${ }^{43}$ returned the final verdict. As Thomas Green has argued, trial jurors 'remained free to say the 'truth' as they knew it, and to reject the conclusions of both juries of presentment and coroners' inquest juries." ${ }^{44}$ The verdicts of the petty jury, recorded in the marginalia of the coroners' and eyre rolls, suggest that trial juries, perhaps under the direction of royal justices, sometimes rejected expressions of local compassion by overturning earlier judgments. Thus, the marginalia in at least 18 cases, record the opinions of both inquest and presentment juries that the self-killers were non compos mentis. At their trials, however, petty juries described them as felons and therefore acting voluntarily. Similarly, in at least 27 cases described by the inquest or presentment jurors as accidents, trial juries later determined them to be suicides. It is important to note that these figures do not represent the actual totals, and many coroners' and eyre or assize rolls do not include any indication of the final verdict. Yet, at 6.3 percent, there is compelling evidence to suggest that trial jurors, who were unfamiliar with the self-killer and his/her family, were less likely to be merciful than were their fellows at earlier stages in the legal process.

\section{Inquest Jurors and Harsh Verdicts}

While familiarity played a decisive role in suicide verdicts, it cannot entirely explain the thinking that underlay the reports of coroners' jurors in many cases of suicide. As Alexander Murray has noted, at times "we find things the other way round: that it is a coroner who judges the question of a suicide's insanity the more harshly." ${ }^{5}$ Murray explains these puzzling exceptions as an inevitable product of an unforgiving and inflexible system, noting in particular the "frequent amercements of coroners. They learned to fear the Eyre judges, knowing that excessive leniency might be punished." 46 In making this statement, Murray attributes more authority and autonomy to the coroner (apart from his jury) than have other historians. ${ }^{47}$ His conclusion is at odds with Carrie Smith's image of the slipshod, uncaring, and self-centered coroner, "prepared to turn a blind eye if the weather was particularly bad." ${ }^{48}$ Smith's depiction highlights the coroner at his worst; even at his best, the county coroner drawn from outside the locality, however, was at the mercy of his inquest jury to determine a verdict in a death about which he knew absolutely nothing. Despite Murray's 
amplified perception of the role of the coroner, he has nevertheless identified an incongruity that is noteworthy. Why did inquest jurors, at times willing to demonstrate compassion and judicial lenience, sometimes also pronounce judgments of the most severe kind?

Although the terse nature of the records prevent us from drawing definitive conclusions, once again, familiarity with the self-killer may offer some clues to help answer this question. Historians of the law have noted frequently that, in England, juries' verdicts "were based not on evidence or testimony, but on assertion and reputation." ${ }^{49}$ This tendency became even more pertinent in the fourteenth century with a growing emphasis on moral lifestyle and good governance. ${ }^{50}$ Because so much of the decision-making process at every stage of the medieval judicial process is hidden from the historian, it is simply not possible in most cases to determine the degree to which the character of the self-killer influenced the jury's decision in a declaration of suicide. Yet, the inclusion in formal indictments of what John Bellamy has termed "phrases of afforcement" offers a promising way to interpret perceptions of the accused. ${ }^{51}$ Jurors deliberately incorporated into indictments words or phrases designed to emphasize the stealthy and private nature of the crime (and thus its depravity), and by such means indicate to petty jurors the need to invoke the full weight of the law." "In cases of self-killing, such terms might include "by night," "murder," "with malice aforethought," "behind closed doors," and "alone." Although Thomas Green traces the significance of stealth as a factor in determining communal perceptions back to the Anglo-Saxon period, ${ }^{53}$ the practice of conveying these beliefs through a set terminology seems to have become sophisticated only in the fourteenth century; thus, one might expect to find more frequent occurrences of these phrases in coroners' rather than eyre or assize rolls. The records confirm this observation: 32 of the 526 cases of self-killing (or 6 percent) in the eyre or assize rolls included terms that Bellamy would describe as phrases of afforcement; no fewer than 40 of the 192 cases of self-killing (or 21 percent) in the coroners' rolls employed such phrases. In some of these entries, local juries employed multiple phrases of afforcement, demonstrating their determination to condemn some self-killers. For example, when William Houdlon of Cambridgeshire, aged 60 years and more, hanged himself at Chesterston, the coroner's roll meticulously notes that he did so in the wee hours of the morning (between the hours of prime and terce) and with malice aforethought, without the assent of anyone. ${ }^{54}$

The ubiquity of phrases of afforcement in narratives of self-killing appearing in coroners' rolls is telling, and suggests that inquest jurors favored verdicts of an extreme nature, according to circumstances that they themselves determined. Thus, while coroners' juries sometimes demonstrate a touching compassion, they might also be embittered and vindictive. Inquest jurors were among those most deeply affected by a self-killing, so intense sensitivity or wrath seems consequently justified. In the context of the turbulent, seemingly crisis-ridden fourteenth century, such a high number 
of cases employing phrases of afforcement may equally be interpreted in a different light. It is entirely possible that jurors sought to secure convictions out of a determination to make specific self-killers personally responsible for the consequences of their actions, while at the same time deterring others from following suit.

Regrettably, because indictments do not generally provide insight into the character of the accused, it is difficult to understand clearly why certain self-killers seem to have been deserving of a local jury's censure. At times, it seems fairly clear that a jury's reproach was value-ridden. For example, a 1503 coroner's roll from Nottinghamshire recounts the story of Joan Wynspere of Basford, a pregnant "syngilwoman" who died during a botched abortion, and yet was still reported by the coroner's jury as a suicide. ${ }^{55}$ Both Sandy Bardsley and Marjorie McIntosh have highlighted the mounting hostility at the end of the medieval period of the local courts to women, and in particular single women, who failed to conform to popular expectations of women as passive, moral creatures. ${ }^{56}$ Thus, it should come as no surprise that such a woman, whose behavior confirmed popular fears of loose morality and engaged in an act equated by both church and state with murder, might fall victim to communal censure. ${ }^{57}$

\section{Conclusion}

Even today, when a member of a community commits suicide, it is no easy matter to address. Families, friends, and neighbors are devastated by the loss. In medieval England, however, the consequences extended well beyond psychological and emotional distress. Popular fears of diabolical incitement combined with religious and legal proscription to cast an especially onerous pall on the dead. As a result, cases of self-killing reported to royal officials were likely to become verdicts of felony. Torn between the competing demands of community, church, and state, jurors seem to have found it difficult to exculpate suicides openly and frequently. Nonetheless, it is clear that jurors sometimes produced kindly judgments out of compassion, not only for the families of the dead, but also for the dead themselves. While both coroner's inquest and presentment jurors upheld a communal sense of justice, inquest jurors seem to have been less likely to brand a self-killing felonious. In addition, they were more willing than either presentment or trial jurors to explain self-killings as acts of insanity. Inquest jurors were usually assembled from the immediate neighborhood of the dead person, and were thus most likely to be affected personally by a suicide. Their compassion must therefore be regarded as a natural and reasonable response to human tragedy.

And yet, inquest jurors sometimes also returned verdicts of the most condemnatory sort. The frequent use of phrases of afforcement, words, or terms chosen to emphasize the furtive and depraved nature of a self-killer's deed, reflect such manifestations of local antagonism. Here, too, familiarity 
with the dead appears to explain the jury's behavior. It is possible that jurors believed self-killers of low standing or repute in a community were deserving of a harsh sentence, and used their verdicts to hold such individuals personally responsible for the consequences of their actions, serve as a deterrent to others, or even encourage moral living in those left behind. At the very least, this study confirms that suicide in medieval England provoked strong feelings among a population, and that inquest jurors, in particular, representing their communities, were prepared to do whatever it took to minimize the damage such a death might inflict on the well being of medieval communities.

\section{Acknowledgments}

Funding for this research was generously provided by the Social Sciences and Humanities Research Council of Canada, and by Dalhousie University. Many thanks also to Cynthia Neville, Tim Stretton, the participants of the Thirty-Eighth International Congress of Medieval Studies at Kalamazoo (May, 2003), and the anonymous reader for this journal for comments on earlier drafts of this paper.

\section{Notes}

$\star$ Correspondence address: Assistant Professor, History Department, Chair of Medieval Studies, Loyola University, New Orleans, LA 70001, USA. Email: sbutler@loyno.edu.

${ }^{1}$ For example, see J. G. Bellamy, The Criminal Trial in Later Medieval England: Felony before the Courts from Edward 1 to the Sixteenth Century (Toronto: Pontifical Institute of Mediaeval Studies, 1998); Thomas A. Green, Verdict According to Conscience: Perspectives on the English Criminal Trial Jury 1200-1800 (Chicago: University of Chicago Press, 1985); Gervase Rosser, "Sanctuary and Social Negotiation in Medieval England," in John Blair and Brian Golding (eds.), The Cloister and the World: Essays in Medieval History in Honour of Barbara Harvey (Oxford: Clarendon Press, 1996), 57-79.

2 J. M. Kaye, “The Early History of Murder and Manslaughter," Law Quarterly Review, 82 (1967): 365-95, 569-601; see also ch. 2 of Green, Verdict According to Conscience.

${ }^{3}$ For a discussion of the profits of criminal justice, see Anne R. DeWindt and Edwin B. DeWindt (eds.), Royal Justice and the Medieval English Countryside, pt. 1 (Toronto: University of Toronto Press, 1981), the introduction.

${ }^{4}$ Georges Minois, History of Suicide: Voluntary Death in Western Culture (Baltimore and London: Johns Hopkins University Press, 1999), trans. by Lydia G. Cochrane, 25; see Roy Porter, Madness: A Brief History (Oxford: Oxford University Press, 2002), 23.

${ }^{5}$ Eamon Duffy, The Stripping of the Altars: Traditional Religion in England, c.1400-c.1580 (New Haven and London: Yale University Press, 1992), 303.

${ }^{6}$ Paul Binski, Medieval Death: Ritual and Representation (Ithaca: Cornell University Press, 1996), 24.

${ }^{7}$ Minois, History of Suicide, 35.

${ }^{8}$ The earliest example of a documented crossroads burial is dated to 1510 with the death of Robert Browner in Suffolk, who hanged himself because of fiscal incompetence. See Andrew Reynolds, "Burials, Boundaries and Charters in Anglo-Saxon England: A Reassessment," in Sam Lucy and Andrew Reynolds (eds.), Burial in Early Medieval England and Wales (London: Society for Medieval Archaeology, 2002), 181-3. For a discussion of the origins of this practice, see Robert Halliday, "Wayside Graves and Crossroads Burials," Proceedings of the Cambridge Antiquarian Society, 84 (1996 for 1995): 113-18; Michael MacDonald and Terence R. Murphy, Sleepless Souls: Suicide in Early Modern England (Oxford: Oxford University Press, 1990), 18-19. 
${ }^{9}$ Although the evidence for the medieval period is scanty, it is clear that belief in the walking dead and the efficacy of staking or destruction of the corpse was a part of northern folklore. Burchard of Worms, for example, in his eleventh century book of penitentials discusses the staking of children who died without baptism to prevent them rising from the dead. See John T. McNeill and Helena M. Gamer (eds.), Medieval Handbooks of Penance (New York: Columbia University Press, 1938; rpt. 1990), 339. The "walking dead" was also a relatively common English theme in medieval literature, appearing in works by William of Malmsebury, Walter Map, and William Newburgh. See Jacqueline Simpson, "Repentant Soul or Walking Corpse? Debatable Apparitions in Medieval England," Folklore, 114 (2003): 389-402.

${ }^{10}$ Jean-Claude Schmitt, Ghosts in the Middle Ages: The Living and the Dead in Medieval Society (Chicago and London: University of Chicago Press, 1998), 6-7.

${ }^{11}$ Minois, History of Suicide, 36. A case of suicide from Northumberland in 1256 confirms that families were concerned about public appearances where suicide is concerned. When William, son of Eda, wife of Henry le Muner, found his mother's hanging body, he cut her down, put her in bed, and told the neighbors she had died a natural death. It was only after she had been buried in consecrated ground that her transgression became known. See W. Page (ed.), Three Early Assize Rolls for the County of Northumberland (Durham: Surtees Society, vol. 88, 1891), 121-2.

12 P. Hair, "A Note on the Incidence of Tudor Suicides," Local Population Studies, 5 (1970): 3643; MacDonald and Murphy, Sleepless Souls, 16-23.

${ }^{13}$ Alexander Murray, Suicide in the Middle Ages, Vol. 1: The Violent against Themselves (Oxford: Oxford University Press, 1998), 169.

${ }^{14}$ Murray, Suicide in the Middle Ages, 169.

${ }^{15}$ R. F. Hunnisett, The Medieval Coroner (Cambridge: Cambridge University Press, 1961), 14-15.

${ }^{16}$ B. W. McLane, "Juror Attitudes towards Local Disorder: The Evidence of the 1328 Lincolnshire Trailbaston Proceedings," in J. S. Cockburn and Thomas A. Green (eds.), Twelve Good Men and True: The Criminal Trial Jury in England, 1200-1800 (Princeton: Princeton University Press, 1988), 42.

${ }^{17}$ Carrie Smith “Medieval Coroners' Rolls: Legal Fiction or Historical Fact?” in Diana E. S. Dunn (ed.), Courts, Counties and the Capital in the Later Middle Ages (New York: Stroud, 1996), 115.

${ }^{18}$ Roger D. Groot, "When Suicide Became Felony," The Journal of Legal History, 21/1 (2000): 7.

${ }^{19}$ Gwen Seabourne and Alice Seabourne, "The Law on Suicide in Medieval England," The Journal of Legal History 21/1 (2000): 35.

20 The National Archives, Kew, Surrey (hereafter abbreviated as TNA) JUST 1/46, m. 20d (Beds.).

${ }^{21}$ Granted, this does not imply that 79 percent were described as deaths by misadventure; simply, even in narratives where the act appears to have been deliberate, the term "felony" (in any of its variants) was not included in the text.

${ }^{22}$ Leonard W. Levy, The Palladium of Justice: Origins of Trial by Jury (Chicago: Ivan R. Dee, 1999), 38 .

${ }^{23}$ Green, Verdict According to Conscience, 77.

${ }^{24}$ MacDonald and Murphy, Sleepless Souls, 23.

${ }^{25}$ Murray, Suicide in the Middle Ages, 384.

26 TNA JUST 1/223, mm. 1 and 3d (Co. Durham), deaths of Roger, son of Nicholas Despencer of Gainford, and William of Preston.

${ }^{27}$ Of the 197 cases of self-killings in coroners' rolls, 9 or 4.6 percent were said to have been accidental; of the 526 cases of self-killing recorded in eyre or assize rolls, 24 or 4.6 percent were reported as deaths by misadventure.

${ }^{28}$ MacDonald and Murphy, Sleepless Souls, 20.

${ }^{29}$ TNA JUST $1 / 725$, m. $12 \mathrm{~d}$ (Rutland).

${ }^{30}$ The sermon literature of the period includes a number of well-known exempla, such as the tale of the anchoress tempted by the devil to hang herself, but foiled by a shrewd confessor. J. Klapper (ed.), Erzählungen des Mittelalters. Wort und Brauch, XII (Breslau: M. \& H. Marcus, 1914), no. 151.

${ }_{31}$ MacDonald and Murphy, Sleepless Souls, 20.

32 TNA JUST 1/683, m. 62d (Notts.), death of Alice who was the wife of William de Aston of Normanton.

${ }^{33}$ Jane Sims, "Memories of a Bright, Happy Woman," London Free Press, August 12, 2000.

${ }^{34}$ Michelle Shepard and Hamida Ghafour, "Baby Dies in Mother's Suicide Bid," The Toronto Sun, August 12, 2000. 
35 Steve Simmons, "The Best of Everything," The Toronto Sun, August 14, 2000.

36 TNA JUST 2/23, m. 3 (Cambs.).

37 TNA JUST 2/215, m. 35 (Yorks.).

38 Green, Verdict According to Conscience, 52.

39 TNA JUST 2/67, m. 50 (Lincs.).

40 TNA JUST 2/145, m. 1 (Shrops.).

41 Obviously some drownings might have been easier to rationalize than others. For example, jurors might have found it difficult to explain away the rope tied around both a rock and William le Mere de Essheby's neck when his drowned body was dragged from a marl pit (TNA JUST $1 / 635$, m. 42, Northants.), or the fact that Thomas Warner of Moulton's feet and hands were tied together when he drowned (TNA JUST 2/67, m. 26d, Lincs.). In the vast majority of suicides by drowning, however, the records do not offer any indication that the felon deliberately sought to weigh down his/her body.

42 B. W. McLane, "Juror Attitudes towards Local Disorder," 59.

${ }^{43}$ On the issue of the composition of trial juries, see articles by J. B. Post and Edward Powell in Twelve Good Men and True; and, G. Fisher, "The Jury's Rise as Lie Detector," Yale Law Journal, 107 (1997): 575-713.

${ }^{44}$ Green, Verdict According to Conscience, 52.

${ }^{45}$ Murray, Suicide in the Middle Ages, 169.

${ }^{46}$ Murray, Suicide in the Middle Ages, 170.

${ }^{47}$ For example, see Carrie Smith's discussion of the judicial process. She attributes the responsibility of determining a judgment to the freemen and tithingmen associated with the inquest. The coroners, who often appear to have been reluctant even to carry out their duties without a bribe of some substance, were concerned most with creating an official record. See Smith, "Medieval Coroners' Rolls."

48 Smith, "Medieval Coroners' Rolls," 100.

49 Trevor Dean, Crime in Medieval Europe 1200-1500 (Edinburgh: Longman, 2001), 13. See also McLane, "Juror Attitudes towards Local Disorder," 57, or Frederick Pollock and F. W. Maitland, The History of English Law, Before the Time of Edward I (Cambridge: Cambridge University Press, 1898), vol. II, 655: "Trial by Jury Must Have Been in the Main Trial by General Repute."

50 Marjorie Keniston McIntosh, Controlling Misbehavior in England, 1370-1600 (Cambridge: Cambridge University Press, 1998); Barbara A. Hanawalt, " 'Good Governance' in the Medieval and Early Modern Context," Journal of British Studies, 37 (1998): 246-57.

51 Bellamy, The Criminal Trial in Later Medieval England, 29.

${ }^{52}$ For a fuller discussion of the use of phrases of afforcement in cases of suicide, see Sara M. Butler, "Degrees of Culpability: Suicide Verdicts, Mercy, and the Jury in Medieval England," Journal of Medieval and Early Modern Studies, 36/2 (2006): 263-90.

53 See Green, Verdict According to Conscience, ch. 2: "Societal Concepts of Criminal Liability and Jury Nullification of the Law in the Thirteenth and Fourteenth Centuries," 28-64.

54 TNA JUST 2/18, m. 52 (Cambs.).

${ }^{55}$ Hunnisett, Calendar of Nottinghamshire Coroners' Inquests, 8.

56 Sandy Bardsley, "Sin, Speech and Scolding in Late Medieval England," in Thelma Fenser and Daniel Lord Smail (eds.), Fama: The Politics of Talk and Reputation in Medieval Europe (Ithaca: Cornell University Press, 2003), 145-64; McIntosh, Controlling Misbehavior in England, 191.

57 See Sara M. Butler, “Abortion by Assault: Violence against Pregnant Women in Thirteenthand Fourteenth-Century England,” Journal of Women's History, 17/4 (2005), 9-10.

\section{Bibliography}

\section{PRIMARY SOURCES}

\section{Manuscript}

The National Archives, Kew, Surrey (TNA) JUST 1

Beds. (24, 46); Berks. (36, 44); Bucks. (55, 63); Cambs. (86, 95); Cornwall (111, 118); Cumberland (133, 135); Derby (148, 166); Devon (175, 181); Dorset (204, 213); Co. Durham (223); Essex (in entirety); Gloucs. (274, 278); Hants. (780, 787); Hereford (300C, 302); Herts. (318, 325); Hunts. 
(343, 345); Kent (369, 374); Lancs. (409); Lancaster (436, 437); Leics. (455, 461); Lincs. (480, 488); Middlesex (538); Norfolk (568, 573); Northants. (623, 635); Northumberland (653); Notts. (664, 683); Oxon. (700, 705); Rutland (722, 725); Shrops. (737, 739); Somerset (759); Staff. (806); Suffolk (827); Surrey (872, 876); Sussex (930); Warwick (951A, 956); Westmorland (982, 986); Wilts. (996, 1005 Pt. 2); Worcs. (1022, 1025); Yorks. (in entirety).

TNA JUST 2 (in entirety)

Print

Cam, Helen M. (ed.), The Eyre of London 14 Edward II A.D. 1321, vols. 85 and 86. (London: Selden Society, 1968).

Chew, Helena M., and Weinbaum, Martin (eds). The London Eyre of 1244, vol. 6. (London: London Record Society, 1970).

Clanchy, M.T. (ed.), The Roll and Writ File of the Berkshire Eyre of 1248, vol. 90. (London: Selden Society, 1973).

DeWindt, Anne Reiber, and DeWindt, Edwin Brezette (eds). Royal Justice and the Medieval English Countryside: The Huntingdonshire Eyre of 1286, the Ramsey Abbey Banlieu Court of 1287, and the Assizes of 1287-88, Pt. 1 (Toronto:Toronto University Press, 1981).

Fowler, G. Herbert (ed.), Roll of the Justices of Eyre at Bedford, 1227, vol. 3. (Streatley: Bedfordshire Historical Record Society, 1917).

Fowler, G. Herbert (ed.), Calendar of the Roll of the Justices on Eyre, 1247, vol. 21. (Streatley: Bedfordshire Historical Record Society, 1939).

Gross, Charles (ed.), Select Cases from the Coroners' Rolls A.D. 1265-1413 with a Brief Account of the History of the Office of Coroner, vol. 9. (London: Selden Society, 1896).

Harding, Alan (ed.), The Roll of the Shropshire Eyre of 1256, vol. 96. (London: Selden Society, 1981).

Hunnisett, R. F. (ed.) Bedfordshire Coroners' Rolls, vol. 41. (Streatley: Bedfordshire Historical Record Society, 1960).

Hunnisett, R. F. (ed.) Calendar of Nottinghamshire Coroners' Inquests 1485-1558, vol. 25. (Nottingham: Thoroton Society Record Series, 1969).

Hunnisett, R. F. (ed.) Sussex Coroners' Inquests 1558-1603 (London: Public Record Office, 1996).

Meekings, C. A. F. (ed.), Crown Pleas of the Wiltshire Eyre, 1249, vol. 15. (Devizes: Wiltshire Archaeological and Natural History Society, Records Branch, 1961).

Page, W. (ed.), Three Early Assize Rolls for the County of Northumberland, vol. 88. (Durham: Surtees Society, 1891).

Palmer, W. M., The Assizes held at Cambridge, A.D. 1260: Being a Condensed Translation of Assize Roll 82 in the Public Record Office, with An Introduction (Devizes: Wiltshire Archaeological and Natural History Society, 1930).

Rogers, J. E. Thorold (ed.), Oxford City Documents: Financial and Judicial, 1268-1665, vol. 18. (Oxford: Oxford Historical Society, 1891).

Sharpe, Reginald R. (ed.), Calendar of Coroner's Rolls of the City of London A.D. 1300-1378 (London: Richard Clay \& Sons, 1913).

Stenton, Doris Mary (ed.), The Earliest Lincolnshire Assize Rolls A.D. 1202-1209, vol. 22. (London: The Lincoln Record Society, 1926).

Stenton, Doris Mary (ed.), Rolls of the Justices in Eyre, Being the Rolls of Pleas and Assizes for Yorkshire in 3 Henry III (1218-19), vol. 56. (London: Selden Society, 1937).

Stenton, Doris Mary (ed.), Pleas before the King or his Justices, 1198-1210. Vol. II: Rolls or Fragments of Rolls from the Years 1198, 1201 and 1202, vol. 67, pt. 2. (London: Selden Society, 1952).

Summerson, Henry (ed.), Crown Pleas of the Devon Eyre of 1238, New Series, vol. 28. (Devon: Devon and Cornwall Record Society, 1985).

Weinbaum, Martin (ed.), The London Eyre of 1276, vol. 12. (London: London Record Society, 1976).

\section{SECONDARY SOURCES}

Bardsley, Sandy, "Sin, Speech and Scolding in Late Medieval England," in Thelma Fenser and Daniel Lord Smail (eds.), Fama: The Politics of Talk and Reputation in Medieval Europe (Ithaca: Cornell University Press, 2003), 145-64. 
Bellamy, J. G., The Criminal Trial in Later Medieval England: Felony before the Courts from Edward I to the Sixteenth Century (Toronto: University of Toronto Press, 1998).

Binski, Paul, Medieval Death: Ritual and Representation (Ithaca: Cornell University Press, 1996).

Butler, Sara M., "Degrees of Culpability: Suicide Verdicts, Mercy, and the Jury in Medieval England," Journal of Medieval and Early Modern Studies, 36/2 (2006): 263-90.

Butler, Sara M., “Abortion by Assault: Violence against Pregnant Women in Thirteenth-and Fourteenth-Century England,” Journal of Women's History, 17/4 (2005): 9-31.

Dean, Trevor, Crime in Medieval Europe 1200-1500 (Edinburgh: Longman, 2001).

Duffy, Eamon, The Stripping of the Altars: Traditional Religion in England, c.1400-c.1580 (New Haven and London:Yale University Press, 1992).

Fisher, G., "The Jury's Rise as Lie Detector,” Yale Law Journal, 107 (1997): 575-613.

Green, Thomas A., Verdict According to Conscience: Perspectives on the English Criminal Trial Jury 1200-1800 (Chicago: University of Chicago Press, 1985).

Groot, Roger D., "When Suicide Became Felony," The Journal of Legal History, 21.1 (2000): 1-20.

Hair, P., "A Note on the Incidence of Tudor Suicides," Local Population Studies, 5 (1970): 36-43.

Halliday, Robert, "Wayside Graves and Crossroads Burials," Proceedings of the Cambridge Antiquarian Society, 84 (1996 for 1995): 113-18.

Hanawalt, Barbara A., "'Good Governance' in the Medieval and Early Modern Context," Journal of British Studies, 37 (1998): 246-57.

Hunnisett, R. F., The Medieval Coroner (Cambridge: Cambridge University Press, 1961).

Kaye, J. M., “The Early History of Murder and Manslaughter,” Law Quarterly Review, 82 (1967): 365-95, 569-601.

Levy, Leonard W., The Palladium of Justice: Origins of Trial by Jury (Chicago: Ivan R. Dee, 1999).

MacDonald, Michael, and Murphy, Terrence R., Sleepless Souls: Suicide in Early Modern England (Oxford: Oxford University Press, 1990).

McIntosh, Marjorie Keniston, Controlling Misbehavior in England, 1370-1600 (Cambridge: Cambridge University Press, 1998).

McLane, B. W., “Juror Attitudes towards Local Disorder: The Evidence of the 1328 Lincolnshire Trailbaston Proceedings," in J. S. Cockburn and Thomas A. Green (eds.), Twelve Good Men and True: The Criminal Trial Jury in England, 1200-1800 (Princeton: Princeton University Press, 1988), 33-64.

Minois, Georges, History of Suicide: Voluntary Death in Western Culture, trans. Lydia G. Cochrane (Baltimore and London: Johns Hopkins University Press, 1999).

Murray, Alexander, Suicide in the Middle Ages: Vol. 1: The Violence against Themselves (Oxford: Oxford University Press, 1998).

Pollock, Frederick, and Maitland, F. W., The History of English Law, Before the Time of Edward I, 2 vols. (Cambridge: Cambridge University Press, 1898).

Porter, Roy, Madness: A Brief History (Oxford: Oxford University Press, 2002).

Post, J. B., "Jury Lists and Juries in the Late Fourteenth Century," in Twelve Good Men and True: The Criminal Trial Jury in England, 1200-1800, 65-77.

Powell, Edward, "Jury Trial at Gaol Delivery in the Late Middle Ages: The Midland Circuit, 1400-1429," in Twelve Good Men and True: The Criminal Trial Jury in England, 1200-1800, 78-116.

Reynolds, Andrew, “Burials, Boundaries and Charters in Anglo-Saxon England: A Reassessment," in Sam Lucy and Andrew Reynolds (eds.), Burial in Early Medieval England and Wales (London: Society for Medieval Archaeology, 2002), 71-94.

Rosser, Gervase, "Sanctuary and Social Negotiation in Medieval England," in John Blair and Brian Golding (eds.), The Cloister and the World: Essays in Medieval History in Honour of Barbara Harvey (Oxford: Clarendon Press, 1996), 57-79.

Schmitt, Jean-Claude, Ghosts in the Middle Ages: The Living and the Dead in Medieval Society (Chicago and London: University of Chicago Press, 1998).

Seabourne, Gwen, and Seabourne, Alice, "The Law on Suicide in Medieval England," The Journal of Legal History, 21.1 (2000): 21-48.

Simpson, Jacqueline, "Repentant Soul or Walking Corpse? Debatable Apparitions in Medieval England," Folklore, 114 (2003): 389-402.

Smith, Carrie, “Medieval Crooners' Rolls: Legal Fiction or Historical Fact?” in Diana E. S. Dunn (ed.), Courts, Counties and the Capital in the Later Middle Ages (New York: Stroud, 1996), 93-115. 